\title{
MODEL FOR OPPORTUNITIES ASSESSMENT TO INCREASE THE ENTERPRISE INNOVATION ACTIVITY
}

\author{
Larysa FROLOVA ${ }^{\circledR}$, Kostiantyn ZHADKO ${ }^{\circledR 2}$, Olha ILYASH ${ }^{3^{*}}$, \\ Svitlana YERMAK ${ }^{\mathbb{1}} 4$, Tetiana NOSOVA ${ }^{(15}$ \\ 1, ${ }^{4}$ Entrepreneurship and Trading Department, Odessa National Polytechnic University, Odessa, Ukraine \\ 2, 5 Department of Business and Economics, University of Customs and Finance, Dnipro, Ukraine \\ ${ }^{3}$ Department of Theoretical and Applied Economy, International University of Finance, National Technical \\ University of Ukraine "Igor Sikorsky Kyiv Polytechnic Institute", Kyiv, Ukraine
}

Received 1 August 2020; accepted 2 September 2020

\begin{abstract}
This study shows that the model of assessing the opportunities for innovation activity of enterprises is multivariate and interrelated with such macroeconomic regulators of Ukraine's development as competitive attractiveness of the country, favorable conditions for doing business in the country and innovation activity of enterprises. The use of a three-dimensional matrix of indicators to assess Ukraine's competitive attractiveness allowed us to evaluate the significant impact of changes in Ukraine's Global Innovation Index on the innovation activity of enterprises for the period 2014-2019. Moreover, the greater the value of the indicator of the state's innovation potential is, the higher the level of innovation activity in the country becomes, which significantly increases the positive image of Ukrainian entrepreneurs at the global level and acts as a "green light" for foreign investors. Given the wide range of parameters that must be taken into account in an integrated assessment of innovation activity of an enterprise, we have used the method of component analysis.

The uniqueness of an integrated assessment of innovation activity of an enterprise is carried out in accordance with the concept of value formation of innovations and it is tested on the example of Ferrotrading LLC. The effectiveness of the study consists in the fact that the selected sub-indicators for assessing the innovation activity of the studied enterprise (innovation resources, innovation competencies and innovation abilities) greatly complement the assessment of the opportunities for innovation activity in the proposed model. The conducted study has theoretical and practical significance. It can be used as a basis for further research in this area and can be employed by governments to make management decisions on increasing the innovation activity of business and the state as a whole.
\end{abstract}

Keywords: innovation activity, innovation development, innovation potential, investment attractiveness, model, evaluation, enterprise.

JEL Classification: O120, D220.

\section{Introduction}

Economic growth and enterprise development is possible on the basis of dynamic investment growth. Investments are transformed into innovations and new competitive productions, at the expense of investments technological modernization is carried out, achievement of a certain social effect is provided.

The experience of foreign countries shows that the sources of funds for investment in innovation are divided between public and private finances. However, the conceptual basis of state regulation of innovation in Western Europe and the United States is support for domestic investment by business entities. That is why only about $30.0 \%$ of innovations are invested from public funds (about 200 billion US dollars per year). About $65.0 \%$ of research is financed and implemented at the expense of the companies' own sources (Byrka, 2017). It should be noted that the American model of stimulating innovative business is considered to be the most successful, which is confirmed by its spread from the end of the XX century in many countries. The Federal Government empowers privatesector innovators by addressing the market failures that stymie innovative activity and by ensuring framework conditions friendly to experimentation and innovation (A Strategy for American innovation, 2015). At the same time, such a model requires the state to have sufficient

*Corresponding author. E-mail: oliai@meta.ua 
scientific and technical potential, resource opportunities and appropriate conditions for innovative entrepreneurship in the country. This explains the need to expand the investment support of innovation activities of domestic economic entities.

The lack of monitoring of the reasons for the negative dynamics of Ukraine's investment attractiveness index and its impact on business innovation lead to the spread of corruption, growth of the shadow economy and reduced efficiency of the state's innovation potential (Grechanik, 2007). Based on this, an important empirical question is whether timely monitoring of the competitive attractiveness and favorable conditions for doing business can really help to identify the opportunities to increase the innovation activity of enterprises. As empirical research on this topic is quite rare, especially in emerging countries, which, in fact, include Ukraine, that is why this issue deserves attention.

The scientific gap is reflected in the discussion provisions of the existing theoretical and methodological provisions for assessing the innovation activity of enterprises. After all, most authors consider financing and investment support, the lack of investment and immaturity of institutional elements of the innovation infrastructure to be the most difficult aspect of the study of innovation activity (Natorina, 2017). Along with this, there is a gap in the study of methods for assessing innovation activity, which would take into account the impact of global indices of innovative development of the country and, at the same time, internal indicators of innovation potential of enterprises. Thus, most authors recommend evaluating innovation activity from the standpoint of investment activity, i.e. investment opportunities and investment risks (Maslak \& Talover, 2016; Borsch et al., 2016).

We are convinced that the strategy for building an innovative economy requires the development of a comprehensive system for assessing the opportunities to increase innovative business activity. It is important to analyze the trend towards changes in the global competitiveness index calculated by the World Economic Forum in order to assess Ukraine's competitive attractiveness. While the analysis of innovation activity should be carried out according to the values of the Global Innovation Index. It is also necessary to study the scale of the level of favorable investment business climate of Ukraine and the level of innovation activity of enterprises. At the same time, it is not enough to use only the information of world indices of innovation of economies to identify the opportunities for innovation activity of enterprises. That is why the article attempts to integrally assess the innovation activity of the enterprise on the basis of a component analysis. An assessment of the innovation activity of the enterprise is done according to the concept of value formation of innovations (Lawson, 2001).

According to this concept, the integrated assessment of the enterprise's innovation activity is carried out by such components as innovation resources, innovation competencies, innovation abilities, and, directly, the value of innovation. This assessment gives an idea of the development of innovative business activity in a particular country. The integrated assessment also covers the importance of individual sub-indicators for identifying the unique impact of each sub-indicator on the opportunities to develop the innovation potential of enterprises. The proposed model is valuable in practice for making management decisions to increase the innovation activity of business and the state as a whole.

\section{Literature review}

The importance of finding opportunities to increase the innovation activity of market participants is characterized by a variety of areas of research. Thus, the importance of the impact of scientific and technological progress and the potential accumulated by the country is determined by a number of fundamental and applied research in the field of innovation activity. Most authors convincingly substantiate that objectively the most difficult aspect of innovation activity is its financing and investment provision (Yermak, 2017). In particular, Drugov (2010) considers the mechanism of investment provision as creation of necessary conditions for innovations through the system of creation, processing, accumulation. At the same time, the main barriers to the proper implementation of innovations in domestic production, according to the opinion of Kovtunenko et al. (2019), are the lack of a full flow of innovative products, the weakness of innovative infrastructure, and the lack of financial resources of enterprises. The most rational way out of this situation, scientists see more in increasing investment and innovation activity of the business in the direction of capital investment implementation. However, according to the authors Ilyash et al. (2020), Vasyltsiv et al. (2017) the lack of institutional elements of innovation infrastructure and investment potential of the economy hinder the growth of investment attractiveness of enterprises, and, consequently, their innovative development.

At the same time, Fedulova $(2008,2010)$ supports the synergetic evolutionary model of the enterprise innovation development on the basis of the laws of the life cycle of the organization and the laws of synergetic development of the enterprise. We agree with the author's opinion that the cyclical nature of the innovation process corresponds to the cyclical nature of the enterprise innovation development.

Mamatova (2018) continues the scientific controversy of the study, arguing that the benchmark for the competitiveness of domestic enterprises should be innovation development, effective use of existing innovations and their compliance with modern trends in scientific development. It is necessary to clearly define the innovation strategy to increase the competitiveness of the enterprise, to conduct a thorough comparative analysis of many strategic alternatives based on the choice of criteria and indicators that will 
help quantify the feasibility of the chosen innovation strategy (Lupak, 2015). In the works of Frolova et al. (2019) and Bochkovskii and Gounskii (2018) the technologies of management of innovation development of enterprises are proposed and substantiated, which are based on the choice of strategic methods of innovation business activity assessment. However, they do not reflect the calculation of an integrated opportunities assessment to increase the enterprise innovation activity. In this context, the most successful, in our opinion, is the scientific approach Kramskoy and Kolotyuk (2013), who offer universal methodological approaches to the study of innovation development of enterprises and highlight previously unsolved parts of the overall problem. This approach is based on the algorithm of correlation analysis, which is based on a system of indicators for assessing the impact of national and integration factors of the enterprise innovation activity.

In fact, the whole range of considered problems and scientific controversy allowed the authors to determine the main goal and the most effective model of increasing the innovation activity of enterprises and sound decisions for the development of innovative capabilities of business.

\section{Research methodology}

The choice of methods for assessing the investment activity of the enterprise is due to the ambiguity of the concept of "investment activity" in the scientific economic literature. In the work Karpenko and Filyppova (2016) investment activity of the enterprise is characterized by two aspects: as a characteristic of the investment process and as the intensity of investment. The "investment activity" as a process by Savluk (2011) opinion should be assess from the standpoint of investment flows due to investment activities, results in relation to appropriate categories: investment potential, investment risks, investment attractiveness, investment climate. As well as this category may be identified with the dynamics of investment and allows to judge changes in the intensity of investment activity at the macro, meso and micro levels. Thus, Ilyash et al. (2018) reveals a step-by-step method of evaluating the enterprise in terms of investment development using the appropriate evaluation parameters at the macro, meso and micro levels We came to the conclusion that the position of Korytko (2016) needs additional justification, as he determines investment activity from the standpoint of assessing the interaction of two factors - investment opportunities and investment risks (the probability of achieving investment goals). The level of innovation and investment activity of the enterprise according to Borsch et al. (2016) in this aspect is an integrated indicator that summarizes the multidirectional set of indicators of investment potential and investment risk, each of them is also an integrated indicator that synthesizes a set of certain indicators and characteristics. We agree with the view of Shcherba (2015) who in determining the main factors influencing the innovation and investment activity of the enterprise identifies political, economic, legal, social and other factors that determine the conditions of investment activity and the degree of investment risk. In the work of Byrka (2017) to assess the investment activity of industrial enterprises, it is proposed to use three indicators: the growth rate of capital investment of industrial enterprises, the growth rate of foreign direct investment in industry and the share of industry in total foreign direct investment.

Vyborova and Salyakhova (2013) focus on the application of a wide range of alternative approaches to the analysis of investment activity of enterprises: systemic, complex, structural-logical (Frolova \& Kravcheko, 2014), program-target, normative, control-regulatory (Yermak \& Bugaenko 2016). In general, the results of the methods used to assess the opportunities of increasing innovation activity are the basis for the development and adoption of quality management decisions for enterprise development.

\section{Results}

As identified earlier, the activization of the enterprise innovation and investment activity requires the development of a comprehensive system for opportunities assessing of increasing the enterprise innovation activity in three areas: investment business climate of the country; innovation potential of the country; innovation activity of the enterprise.

Thus, the assessment of the investment business climate of Ukraine was carried out according to three analytical areas of assessment: 1) Competitive Attractiveness of the Country $\left(I_{K A C}\right)$;2) Favourable Conditions for Doing Business in the Country $\left.\left(I_{D B}\right) ; 3\right)$ Innovation Activity $\left(I_{I A}\right)$.

To assess the Competitive Attractiveness of the Country, the tendencies of changing the rating of Ukraine according to the Global Competitiveness Index was analysed (Figure 1). The Global Competitiveness Index of the World Economic Forum is made up of 113 variables, two-thirds of which are the results of a global survey of company executives to cover a wide range of factors influencing the business climate in the countries studied.

In 2019, Ukraine took 85th place, losing 2 positions in the ranking of Global Competitiveness Index of the World Economic Forum. According to the data of the International Institute for Management Development (International Institute for Management Development, 2020) the main factors that positively influenced the value of Ukraine's Global Competitiveness Index are: exchange rate stability, social cohesion, bureaucracy reduction, real GDP growth per capita, central bank policy, improvement of the regulatory framework and the situation with public debt, as well as positive the efficiency of the personal income tax rate, the growth of the share of energy obtained from renewable sources, as well as the improvement of the situation with intellectual property rights.

According to the International Institute for Management Development (International Institute for Management Development, 2020) business survey, the key factors 


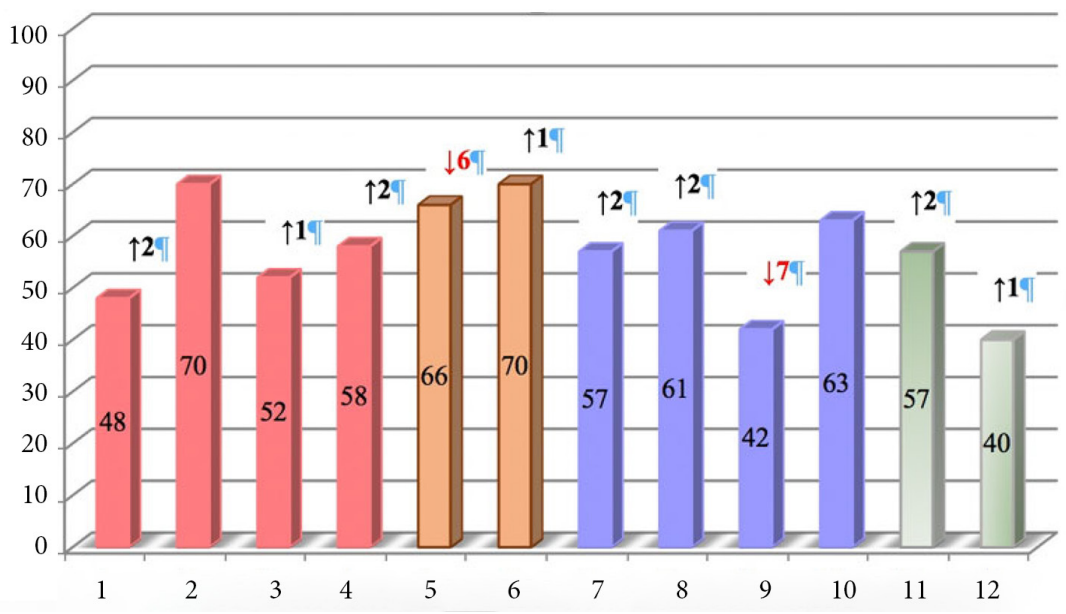

Note: 1 - Institutions; 2 - Infrastructure; 3 - ICT adoption; 4 - Macroeconomic stability; 5 - Health; 6 - Skills; 7 - Product market; 8 - Labour market; 9 - Financial system; 10 - Market size; 11 - Business dynamism; 12 - Innovation capability.

Figure 1. Ukraine's position in the ranking of Global Competitiveness Index of the World Economic Forum, 2019 (developed by the authors based on the source: The Global Innovation Index, 2019)

of economic and, accordingly, investment attractiveness of Ukraine are: skilled labour (65\% of respondents), economic dynamism (53\%), cost competitiveness (45.5\%), high level of education (43.9\%) and effective labour relations $(31.8 \%)$.

To assess the Competitive Attractiveness of Ukraine, the trend of changing the Global Competitiveness Index of the World Economic Forum in 2014-2019 was analyzed (Table 1).

Table 1. Ukraine's position in the Global Competitiveness Index of the World Economic Forum, 2014-2019 (developed by the authors based on the source: The Global Innovation Index, 2019)

\begin{tabular}{|c|c|c|c|}
\hline Period & $\begin{array}{c}\text { Ranking } \\
\text { Place }\end{array}$ & $\begin{array}{c}\text { Total } \\
\text { number of } \\
\text { countries }\end{array}$ & $\begin{array}{c}\text { Index } \\
\text { value }\end{array}$ \\
\hline $2014-2015$ & 76 & 144 & 4.10 \\
\hline $2015-2016$ & 79 & 140 & 4.03 \\
\hline $2016-2017$ & 85 & 138 & 4.00 \\
\hline $2017-2018$ & 83 & 140 & 4.11 \\
\hline $2018-2019$ & 85 & 141 & 4.00 \\
\hline
\end{tabular}

To calculate the Competitive Attractiveness Index of the Country $\left(\mathrm{I}_{\mathrm{KAc}}\right)$, authors suggest to use the following formula:

$$
I_{K A c}=\frac{1}{\sum_{t=1}^{n} R_{t} / n_{t}},
$$

$R_{t}$ - rating of the country according to the Global Competitiveness Index of the World Economic Forum in the t-period; $n_{t}$ is the number of $t$-periods.

$$
\sum_{t=1}^{n} R_{(2014-2019)}=\frac{76+79+85+83+85}{5}=81.6 .
$$

Accordingly, the value of the Competitive Attractiveness Index of Ukraine is as follows:

$$
I_{K A c}=\frac{1}{81.6}=0.122 \text {. }
$$

This reveals that the potential investors consider many other factors, such as the overall quality of an economy's business environment and its national competitiveness, macroeconomic stability, development of the financial system, market size, rule of law, and the quality of the labour force (Doing Business, 2020). In view of this, the Ease of Doing Business Index, compiled by the World Bank, was analyzed to quantify the favourable conditions for doing business in Ukraine. The business conditions under which the Ease of Doing Business rating is calculated consist of 10 indicators: Starting a business (1), Dealing with construction permits (2), Getting electricity (3), Registering property (4), Getting credit (5), Protecting minority investors (6), Paying taxes (7), Trading across borders (8), Enforcing contracts (9), Resolving Insolvency (10). Ease of Doing Business Index in economics it is displayed on a scale from 0 to 100 , where 0 means the lowest value and 100 - the optimal value.

According to the World Bank, in 2019 Ukraine improved the value of the Ease of Doing Business Index on most indicators (Table 2).

According to Doing Business research, Ukraine's increase in the ranking by 7 points (from 71 to 64 places) was the result of government reforms in business (World Bank, 2020):

- Dealing with construction permits (Ukraine streamlined the dealing with construction permits process by eliminating the requirement to hire an external supervisor and introducing an online notification system. Ukraine also made obtaining a construction permit less costly by reducing the contribution fee to the Kyiv City Council); 
Table 2. Ease of Doing Business Indicatiors of Ukraine, 2018-2019 (\%) (developed by the authors based on the source: World Bank, 2020)

\begin{tabular}{|l|c|c|c|}
\hline \multicolumn{1}{|c|}{ Indicator set } & 2018 & 2019 & $\begin{array}{c}\text { Change in points } \\
\text { (\% points) }\end{array}$ \\
\hline Rank & 71 & 64 & +7 \\
\hline Starting a business & 91.1 & 91.1 & $\ldots$ \\
\hline $\begin{array}{l}\text { Dealing with } \\
\text { construction permits }\end{array}$ & 77.2 & 81.1 & 3.9 \\
\hline Getting electricity & 59.2 & 62.5 & 3.3 \\
\hline Registering property & 70 & 71.3 & 1.3 \\
\hline Getting credit & 75 & 75 & $\ldots$ \\
\hline $\begin{array}{l}\text { Protecting minority } \\
\text { investors }\end{array}$ & 66 & 68 & 2 \\
\hline Paying taxes & 79.4 & 78.1 & -1.3 \\
\hline Trading across borders & 77.6 & 80.1 & 2.5 \\
\hline Enforcing contracts & 63.6 & 63.6 & $\ldots$ \\
\hline Resolving Insolvency & 31.7 & 31.4 & -0.3 \\
\hline
\end{tabular}

- Getting electricity (Ukraine made getting electricity easier by streamlining the issuance of technical conditions and by implementing a geographic information system. Ukraine also improved the reliability of power supply by introducing an outage compensation mechanism);

- Registering property (Ukraine made registering property easier by increasing the transparency of the land administration system);

- Getting credit (Ukraine improved access to credit information by establishing a new public credit registry in the National Bank of Ukraine).

- Protecting minority investors (Ukraine strengthened minority investor protections by requiring greater disclosure of transactions with interested parties);

- Trading across borders (Ukraine reduced the time to import by simplifying conformity certification requirements for auto parts).

The following formulas were used to calculate the Favourable Conditions for Doing Business in the country $\left(\mathrm{I}_{D B}\right)$ :

$$
I_{D B}=\frac{\sum_{t=1}^{n} S_{i k}^{D B}}{n},
$$

$S_{i}^{B}$ - standardized value of the $\mathrm{i}_{\mathrm{th}}$ indicator of assessment $(x)$ of Favorable Business Conditions in the country in the $k_{t h}$ period, which is calculated by the formula:

$$
S_{i}^{D B}=\frac{x_{i}}{x_{\max }}
$$

$x_{i}$ is actually a significant indicator of the effectiveness $\left(x_{i}\right)$ of a specialist in doing business in the region in our country; $x_{\max }$ - the maximum (optimal) value of the index $\left(x_{i}\right)$ specialization in doing business in the region (100); $n$ - the number of indicators for assessing the favourable conditions of doing business.
Table 3. Standardized values Ease of Doing Business indicators of Ukraine, 2018-2019, coefficient (calculated by the authors based on the source: World Bank, 2020)

\begin{tabular}{|l|l|l|}
\hline \multicolumn{1}{|c|}{ Indicator set } & 2018 & 2019 \\
\hline \multicolumn{1}{|c|}{ Starting a business } & 0.911 & 0.911 \\
\hline Dealing with construction permits & 0.772 & 0.811 \\
\hline Getting electricity & 0.592 & 0.625 \\
\hline Registering property & 0.700 & 0.713 \\
\hline Getting credit & 0.750 & 0.750 \\
\hline Protecting minority investors & 0.660 & 0.680 \\
\hline Paying taxes & 0.794 & 0.781 \\
\hline Trading across borders & 0.776 & 0.801 \\
\hline Enforcing contracts & 0.636 & 0.636 \\
\hline Resolving Insolvency & 0.317 & 0.314 \\
\hline
\end{tabular}

Accordingly, the value of the Favourable Conditions for Doing Business Index in Ukraine (Table 3) is as follows:

$$
\begin{aligned}
& I_{D B(2018)}=\frac{0.911+0.772+0.592+0.700+0.750+}{10} \\
& \frac{0.660+0.794+0.776+0.636+0.317}{10}=0.691 ; \\
& I_{D B(2018)}=1-\frac{0.911+0.811+0.625+0.73+0.750+}{10} \\
& \underline{0.680+0.781+0.801+0.636+0.314}=0.702 .
\end{aligned}
$$

Increasing the Ukraine's rating in Ease of Doing Business Index-2020 by 7 positions, and, accordingly, improving the value of the Favourable Conditions for Doing Business Index in the country $\left(\mathrm{I}_{\mathrm{DB}}\right)$ from 0.691 to 0.702 is a positive factor for Ukrainian entrepreneurs and a "green light" for foreign investors.

The analysis of the country's innovation activity was carried out according to the values of the Global Innovation Index (Table 4) in 2013-2019. Thus, the higher the value of the indicator, the higher the level of innovation activity in the country.

The following formulas were used to calculate the Innovation Activity Index $\left(I_{I A}\right)$ :

Table 4. Indicators of Ukraine assessment in the Global Innovation Index 2013-2019 (developed by the authors based on the source: The Global Innovation Index, 2019)

\begin{tabular}{|c|c|c|c|c|}
\hline Period & Rank & $\begin{array}{c}\text { Score } \\
(0-100)\end{array}$ & $\begin{array}{c}\text { The degree } \\
\text { Index } \\
\text { Change, } \\
+/-\end{array}$ & $\begin{array}{c}\text { The reference value } \\
\text { of achievement } \\
\text { of the coefficient, } \\
\text { coef. }\end{array}$ \\
\hline $2013-2014$ & 63 & 36.3 & - & 0.363 \\
\hline $2014-2015$ & 64 & 36.5 & 0.2 & 0.365 \\
\hline $2015-2016$ & 56 & 35.7 & -0.8 & 0.357 \\
\hline $2016-2017$ & 50 & 37.6 & 1.9 & 0.376 \\
\hline $2017-2018$ & 43 & 38.5 & 0.9 & 0.385 \\
\hline $2018-2019$ & 47 & 37.4 & -1.1 & 0.374 \\
\hline
\end{tabular}




$$
I_{I A}=\sqrt[k_{t}]{\sum_{i=1}^{t}\left(1-\frac{K_{i}^{t}}{E_{i}}\right)}
$$

$K_{i}^{t}-$ absolute value oh the Global Innovation Index for the $t$-period; $E_{i}$ - reference value of the Global Innovation Index (100); $k_{t}$ - number of $t$-periods.

Accordingly, the value of the Innovation Activity Index $\left(I_{I A}\right)$ of Ukraine is as follows:

$I_{I A}=$

$\sqrt[6]{(1-0.363)+(1-0.365)+(1-0.357)+(1-0.376)+(1-0.385)+(1-0.374)}$ $=0.630$.

According to the European Business Association for 2013-2019, the Investment Attractiveness Index $\left(I_{I P}\right)$ during 2016-2018 had a steady upward trend. In 2019, its value decreased to 2.85 , leaving the neutral zone. The negative dynamics of Ukraine's investment attractiveness index is due to a number of factors: high levels of corruption, lack of land reform, a large percentage of the shadow economy, high pressure from regulators, martial law in the east, smuggling that prevents legal business, and so on.

The following formula was used for the general assessment of the Investment Business Climate $\left(S_{B C}\right)$ of Ukraine:

$$
S_{B C}=\frac{1}{2} \sin \frac{360^{\circ}}{n} \times\left(a_{n i} \times a_{1 i}+\sum_{m=1}^{n-1} a_{m i} \times a_{(m+1) i}\right),
$$

$S_{B C}$ - complex indicator of investment business climate assessment, coefficient; $a_{i}$ - local components of the investment business climate assessment are calculated by the formulas:

$$
\begin{aligned}
& a_{1}=\sqrt{I_{I A c}{ }^{2} \times I_{D B}{ }^{2}-2 \times I_{I A c} \times I_{D B} \times \cos \frac{360^{\circ}}{n}} ; \\
& a_{2}=\sqrt{I_{D B}^{2} \times I_{I A}^{2}-2 \times I_{D B} \times I_{I A} \times \cos \frac{360^{\circ}}{n}} ; \\
& a_{3}=\sqrt{{I_{I A}{ }^{2} \times I_{I A t^{2}}-2 \times I_{I A} \times I_{I A t} \times \cos \frac{360^{\circ}}{n}}_{n}} ; \\
& a_{4}=\sqrt{I_{I A t}^{2} \times I_{I A c}{ }^{2}-2 \times I_{I A t} \times I_{I A c} \times \cos \frac{360^{\circ}}{n}} .
\end{aligned}
$$

$I_{I A c}$ - is an indicator of the Competitive Attractiveness of the Country, coefficient; $I_{D B}$ - an indicator of Favourable Conditions for Doing Business in the Country, the coefficient; $I_{I A}$ - indicator of Innovation Activity, coefficient; $I_{I A t}$ - indicator of Investment Attractiveness of the Country, coefficient; $n$ - the number of indicators for assessing the investment business climate (4).

Accordingly, the values of the local components of the Investment Business Climate assessment will be:

$a_{1}=\sqrt{0.122^{2} \times 0.702^{2}-2 \times 0.122 \times 0.702 \times \cos \frac{360^{\circ}}{4}}=0.804$;

$a_{2}=\sqrt{0.702^{2} \times 0.630^{2}-2 \times 0.702 \times 0.630 \times \cos \frac{360^{\circ}}{4}}=0.592 ;$ $a_{3}=\sqrt{0.630^{2} \times 2.85^{2}-2 \times 0.630 \times 2.85 \times \cos \frac{360^{\circ}}{4}}=4.833 ;$

$a_{4}=\sqrt{2.85^{2} \times 0.122^{2}-2 \times 2.85 \times 0.122 \times \cos \frac{360^{\circ}}{4}}=0.432$.

Accordingly, the value of a general assessment of the Investment Business Climate $\left(S_{B C}\right)$ is as follows:

$S_{B C}=\frac{1}{2} \sin \frac{360^{\circ}}{4} \times$

$(0.804 \times 0.592+0.592 \times 4.833+4.833 \times 0.432+0.432 \times 0.804)$ $=2.252$.

To assess the favourable Investment Business Climate of Ukraine to increase the enterprise innovation activity developed a scale (Table 5):

Table 5. Scale of evaluation of the complex indicator of the Investment Business Climate assessment of Ukraine (developed by the authors)

\begin{tabular}{|c|l|}
\hline $\begin{array}{c}\text { The range of changes in } \\
\text { the values of the complex } \\
\text { indicator }\end{array}$ & \multicolumn{1}{|c|}{ Linguistic assessment } \\
\hline $7.00 \leq S_{B C} \leq 10.00$ & $\begin{array}{l}\text { Very favourable investment } \\
\text { business climate }\end{array}$ \\
\hline $4.00 \leq S_{B C} \leq 6.99$ & $\begin{array}{l}\text { Favourable investment business } \\
\text { climate }\end{array}$ \\
\hline $2.00 \leq S_{B C} \leq 4.00$ & $\begin{array}{l}\text { Moderately favourable } \\
\text { investment business climate }\end{array}$ \\
\hline $1.00 \leq S_{B C} \leq 1.99$ & $\begin{array}{l}\text { Neutral investment business } \\
\text { climate }\end{array}$ \\
\hline $0 \leq S_{B C} \leq 0.99$ & $\begin{array}{l}\text { Unfavourable investment } \\
\text { business climate }\end{array}$ \\
\hline
\end{tabular}

To find the robustness of the study the scale developed accordingly, the Investment Business Climate in Ukraine is assessed as moderately favourable. This indicates that the dynamic growth of investment will positively contribute to the development of innovation in all areas of economic activity.

Opportunities for innovative development and increasing the level of innovation activity of individual enterprises depends on the state of innovation potential of the country as a whole. One of the main indicators, a generalizing indicator for measuring the level and results of the country's innovation potential, is the Global Innovation Index, 2019, which reflects the main components of the innovation potential of countries (Levkivsky, 2017). In view of this, when assessing the opportunities of increasing the enterprise innovation activity, the need to assess the Ukraine's position on the components of the Global Innovation Index (Table 6) is actualized.

The assessment of Ukraine's position on the indicators of the Global Innovation Index shows that the country's innovation potential in international ratings has high 
Table 6. Assessment of Ukraine's position by indicators of the Global Innovation Index (GII), 2014-2019 (developed by the authors based on the source: The Global Innovation Index, 2019)

\begin{tabular}{|c|c|c|c|c|c|c|c|c|c|c|c|c|}
\hline \multirow[b]{2}{*}{ Indicators GII } & \multicolumn{2}{|c|}{2014} & \multicolumn{2}{|c|}{2015} & \multicolumn{2}{|c|}{2016} & \multicolumn{2}{|c|}{2017} & \multicolumn{2}{|c|}{2018} & \multicolumn{2}{|c|}{2019} \\
\hline & $\begin{array}{c}\text { Score } \\
(0-100)\end{array}$ & $\begin{array}{l}\text { Rank } \\
(143)\end{array}$ & $\begin{array}{c}\text { Score } \\
(0-100)\end{array}$ & $\begin{array}{l}\text { Rank } \\
(141)\end{array}$ & $\begin{array}{c}\text { Score } \\
(0-100)\end{array}$ & $\begin{array}{l}\text { Rank } \\
(128)\end{array}$ & $\begin{array}{c}\text { Score } \\
(0-100)\end{array}$ & $\begin{array}{l}\text { Rank } \\
(128)\end{array}$ & $\begin{array}{c}\text { Score } \\
(0-100)\end{array}$ & $\begin{array}{l}\text { Rank } \\
\text { (126) }\end{array}$ & $\begin{array}{c}\text { Score } \\
(0-100)\end{array}$ & $\begin{array}{l}\text { Rank } \\
\text { (129) }\end{array}$ \\
\hline $\begin{array}{l}\text { Global Innovation } \\
\text { Index }\end{array}$ & 36.3 & 63 & 36.5 & 64 & 35.7 & 56 & 37.6 & 50 & 38.5 & 43 & 37.4 & 47 \\
\hline Institutions & 52.9 & 103 & 52.8 & 98 & 48.7 & 101 & 47.9 & 101 & 49.1 & 107 & 53.9 & 96 \\
\hline $\begin{array}{l}\text { Human capital and } \\
\text { research }\end{array}$ & 36.6 & 45 & 40.4 & 36 & 40.8 & 40 & 39.6 & 41 & 37.9 & 43 & 35.6 & 51 \\
\hline Infrastructure & 27.1 & 107 & 26.3 & 112 & 32.3 & 99 & 39.3 & 90 & 38.1 & 89 & 36.0 & 97 \\
\hline Market sophistication & 45.1 & 90 & 43.9 & 89 & 42.1 & 75 & 43.2 & 81 & 42.7 & 89 & 43.3 & 90 \\
\hline Business sophistication & 29.1 & 87 & 32.4 & 78 & 30.6 & 73 & 35.3 & 51 & 34.5 & 46 & 34.8 & 47 \\
\hline $\begin{array}{l}\text { Knowledge and } \\
\text { technology outputs }\end{array}$ & 38.2 & 32 & 36.4 & 34 & 34.1 & 33 & 32.8 & 32 & 36.7 & 27 & 34.6 & 28 \\
\hline Creative outputs & 30.6 & 77 & 31.3 & 75 & 31 & 58 & 35.6 & 49 & 36.5 & 45 & 35.5 & 42 \\
\hline
\end{tabular}

scores on the indicators "Institutions" - 53.9, "Market sophistication" - 43.3, "Infrastructure" - 36.0.

At the same time, to assess the Innovation Potential of Ukraine ( $\left.\mathrm{E}_{\mathrm{IAC}}\right)$, the following formulas should be used (Dokmanic et al., 2015):

$$
E_{I A C}=1-\frac{\sum_{i=1}^{N} C_{i}^{t}}{N \times C_{E}},
$$

$C_{i}^{t}$ - the actual value of the $i_{t h}$ indicator of the Global Innovation Index for the $t$-period (institutions, human capital and research, infrastructure, market sophistication, business sophistication, knowledge and technology outputs, creative outputs); $C_{E}-$ reference value of the $i_{\text {th }}$ indicator of the Global Innovation Index (100); $N$ - the number of indicators of the Global Innovation Index (6).

Accordingly, the value of the Innovation Potential Index of Ukraine $\left(E_{I A C}\right)$ is as follows:

$$
\begin{aligned}
& E_{I A C(2014)}= \\
& 1-\frac{52.9+36.6+27.1+45.1+29.1+38.2+30.6}{6 \times 100}=0.567 \\
& E_{I A C(2015)}= \\
& 1-\frac{52.8+40.4+26.3+43.9+32.4+36.4+31.3}{6 \times 100}=0.561
\end{aligned}
$$

$E_{I A C(2016)}=$

$1-\frac{48.7+40.8+32.3+42.1+30.6+34.1+31}{6 \times 100}=0.567$;

$$
\begin{aligned}
& E_{I A C(2017)}= \\
& 1-\frac{47.9+39.6+39.3+43.2+35.3+32.8+35.6}{6 \times 100}=0.544 ; \\
& E_{I A C(2018)}= \\
& 1-\frac{49.1+37.9+38.1+42.7+34.5+36.7+36.5}{6 \times 100}=0.541 ;
\end{aligned}
$$

$$
\begin{aligned}
& E_{I A C(2019)}= \\
& 1-\frac{53.9+35.6+36+43.3+34.8+34.6+35.5}{6 \times 100}=0.544 .
\end{aligned}
$$

The obtained results of calculations indicate that despite the decrease of Ukraine's position in terms of the Global Innovation Index, the efficiency of realization of Innovation Potential of Ukraine is increasing. In 2019, the Innovation Potential Index of Ukraine was 0.544, compared to its value in 2018 of 0.541 .

Assessment of the enterprise innovation activity is carried out according to the concept of value formation of innovations (Lawson, 2001). According to this concept the integrated estimation of the enterprise innovation activity is carried out in the following directions (Table 7): 1) innovation resources (IR); 2) innovative competencies (IK); 3 ) innovation capacity (LA); 4) the value of innovation (VI).

Table 7. Indicators of the enterprise innovation activity assessment, 2019 (developed by the authors)

\begin{tabular}{|c|l|c|c|c|}
\hline No & \multicolumn{1}{|c|}{ Indicators } & Symbols & $\begin{array}{c}\text { Normative } \\
\text { values } \\
\text { of the } \\
\text { indicators }\end{array}$ & $\begin{array}{c}\text { Average } \\
\text { expertise, } \\
\text { points }\end{array}$ \\
\hline 1 & $\begin{array}{l}\text { Innovative resources } \\
\text { and research } \\
\text { developments }\end{array}$ & $v^{I R}{ }_{1}$ & decrease & 4.36 \\
\hline 2 & $\begin{array}{l}\text { Return on investment } \\
\text { in new products or } \\
\text { services }\end{array}$ & $v^{I R}{ }_{2}$ & increase & 3.21 \\
\hline 3 & $\begin{array}{l}\text { Profitability of } \\
\text { innovations }\end{array}$ & $v^{I R}{ }_{3}$ & increase & 2.14 \\
\hline 4 & $\begin{array}{l}\text { Net value added } \\
\text { created by a portfolio } \\
\text { of new products or } \\
\text { services }\end{array}$ & $v^{I R}{ }_{4}$ & increase & 3.24 \\
\hline
\end{tabular}


End of Table 7

\begin{tabular}{|c|c|c|c|c|}
\hline No & Indicators & Symbols & \begin{tabular}{|c|}
$\begin{array}{c}\text { Normative } \\
\text { values } \\
\text { of the } \\
\text { indicators }\end{array}$ \\
\end{tabular} & $\begin{array}{l}\text { Average } \\
\text { expertise, } \\
\text { points }\end{array}$ \\
\hline 5 & $\begin{array}{l}\text { Share of new ideas } \\
\text { that were funded }\end{array}$ & $v^{I R}{ }_{5}$ & increase & 1.36 \\
\hline 6 & $\begin{array}{l}\text { Customer satisfaction } \\
\text { with new products or } \\
\text { services }\end{array}$ & $v^{I R}{ }_{6}$ & increase & 4.47 \\
\hline 7 & $\begin{array}{l}\text { Share of intangible } \\
\text { assets }\end{array}$ & $v^{I R}{ }_{7}$ & increase & 1.15 \\
\hline 8 & $\begin{array}{l}\text { The share of material } \\
\text { costs in the cost } \\
\text { structure }\end{array}$ & $v^{I R_{8}}$ & decrease & 3.21 \\
\hline \multicolumn{5}{|c|}{ Innovative competencies } \\
\hline 9 & $\begin{array}{l}\text { Intellectual readiness } \\
\text { of staff for innovation }\end{array}$ & $v^{I K}{ }_{1}$ & increase & 4.54 \\
\hline 10 & $\begin{array}{l}\text { The share of } \\
\text { employees who are } \\
\text { actively involved in } \\
\text { the implementation } \\
\text { of innovations }\end{array}$ & $v_{2}^{I K}$ & increase & 4.61 \\
\hline 11 & $\begin{array}{l}\text { The number of } \\
\text { new ideas that have } \\
\text { emerged in the } \\
\text { enterprise }\end{array}$ & $v_{3}^{I K_{3}}$ & increase & 3.32 \\
\hline 12 & $\begin{array}{l}\text { Number of new } \\
\text { ideas attracted from } \\
\text { outside }\end{array}$ & $v_{4}^{I K_{4}}$ & increase & 2.12 \\
\hline 13 & $\begin{array}{l}\text { Activity of patent- } \\
\text { licensing activity }\end{array}$ & $v^{I K_{5}}$ & increase & 4.54 \\
\hline \multicolumn{5}{|c|}{ Innovative abilities } \\
\hline 14 & Market capitalization & $v^{I A}{ }_{1}$ & increase & 2.45 \\
\hline 15 & The cost of business & $v^{I A}{ }_{2}$ & increase & 3.68 \\
\hline 16 & Margin income ratio & $v^{I A}{ }_{3}$ & increase & 3.64 \\
\hline 17 & $\begin{array}{l}\text { Availability of } \\
\text { innovative proposals } \\
\text { and concepts at } \\
\text { the enterprise } \\
\text { that are awaiting } \\
\text { consideration }\end{array}$ & $v_{4}^{I A}$ & increase & 4.98 \\
\hline \multicolumn{5}{|c|}{ The value of innovation } \\
\hline 18 & Inner creativity & $v^{V I}{ }_{1}$ & increase & 3.32 \\
\hline 19 & External creativity & $v_{1}^{V I}$ & increase & 2.23 \\
\hline 20 & $\begin{array}{l}\text { In-house cross- } \\
\text { exchange of } \\
\text { innovative ideas }\end{array}$ & $v^{V I}{ }_{1}$ & increase & 4.73 \\
\hline 21 & $\begin{array}{l}\text { Selection of } \\
\text { innovative ideas }\end{array}$ & $v^{V I}{ }_{1}$ & increase & 3.32 \\
\hline 22 & $\begin{array}{l}\text { Development and } \\
\text { dissemination of } \\
\text { innovative ideas in } \\
\text { the activity }\end{array}$ & $v^{V I}{ }_{1}$ & increase & 4.36 \\
\hline
\end{tabular}

To assess the level of innovation activity of enterprises, an expert method was used, according to which each group of indicators is evaluated on the following scale: 0 the impact of the indicator on the enterprise innovation activity is absent; 1 - very low degree of influence; 2 - low degree of influence; 3 - moderate degree of influence; 4 high degree of influence; 5 - very high degree of influence.

Given the wide range of parameters that must be taken into account when assessing innovation activity, component analysis is used for integrated assessment (Mishra et al., 2017). The integrated indicator of the Enterprise Innovation Activity (VIA) is calculated by the formula:

$$
\begin{aligned}
& V^{I A}=\alpha_{v^{I R}} \times \sum_{I=1}^{8}\left(v^{I R} \times \beta_{v^{I R}}\right)+\alpha_{v^{I K}} \times \sum_{I=1}^{5}\left(v^{I K} \times \beta_{v^{I K}}\right)+ \\
& \alpha_{v^{I A}} \times \sum_{I=1}^{4}\left(v^{I A} \times \beta_{v^{I A}}\right)+\alpha_{v^{M}} \times \sum_{I=1}^{5}\left(v^{V I} \times \beta_{v^{V I}}\right),
\end{aligned}
$$

$\alpha_{j}$ - weighting factor of the $j_{\text {th }}$ assessment group (innovative resources, innovative competencies, innovative abilities, values of innovations), which affect the level of the enterprise innovation activity, coefficient; $v^{I R, I K, L A, V I}-$ the value of the $i_{t h}$ indicator of the $j_{t h}$ group of assessment of the enterprise innovation activity ( $I R$ - innovative resources, $I K$ - innovative competencies, $L A$ - innovative abilities, $V I$ - values of innovations), coefficient; $\beta_{i}$ - weighting factor of the $k_{t h}$ indicator of the enterprise innovation activity assessment of the $j_{\text {th }}$ group of parameters, coefficient.

The values of the coefficient weights of each group of evaluation indicators were determined on the basis of the randomization method (Wang et al., 2019). The essence of which is that the definition of weightiness can take only a finite set of possible values:

$$
\alpha_{j}\left(\beta_{i}\right) \in F_{L}=\langle 0,1 / L, \ldots L-1 / L, 1\rangle
$$

$\beta_{i}$ - the weightiness coefficient; $L$ - the definite natural number $(L>m) ; m$ - the number of indicators in the evaluation group.

According to the requirements of the randomization method, the total number $\mathrm{K}$ of possible realizations of the $\mathrm{m}$ - dimensional random vector is finite, $R=(L+m-1)$. It is believed that the rank vector is subject to the Dirichlet distribution $\left(\beta_{i}, \ldots, \beta_{n}\right)$. Substituting a randomized vector of weights instead of a deterministic one allows to obtain a randomized generalized complex indicator, which can be interpreted as a "numerical image of n-information" and combine information about individual values of property indicators with non-numerical, inaccurate and fuzzy information about the significance of these indicators.

The obtained results of calculations of the corresponding weighting factors ( $\alpha j$ and $\beta i$ ) allow to calculate the enterprise Innovation Activity Integral Indicator $\left(V^{I A}\right)$ in 2019:

$$
\begin{aligned}
& V_{2019}^{I A}=0.321 \times 0.496+0.209 \times 1.315+ \\
& 0.221 \times 2.641+0.249 \times 1.618=1.419
\end{aligned}
$$

In order to identify the actual level of the enterprise Innovation Activity developed an appropriate scale ( $\mathrm{Ta}-$ ble 8$)$. 
Table 8. The identification scale of the enterprise Innovation Activity Integral Indicator (developed by the authors)

\begin{tabular}{|c|c|}
\hline $\begin{array}{c}\text { The range of values of the } \\
\text { Innovation Activity Integral } \\
\text { Indicator }\left(V^{I A}\right)\end{array}$ & $\begin{array}{c}\text { The range of values of the } \\
\text { Innovation Activity Index }\end{array}$ \\
\hline $1.51 \leq S_{B C} \leq 3.00$ & High \\
\hline $1.01 \leq S_{B C} \leq 2.00$ & Average \\
\hline $1.00 \leq S_{B C} \leq 0.51$ & Low \\
\hline $0 \leq S_{B C} \leq 0.5$ & Null \\
\hline
\end{tabular}

According to the calculations, the value of the Innovation Activity Integral Indicator $\left(V^{I A}\right)$ of Ferrotrading LLC in 2019 is 1.419 , which, according to the identification scale (Table 8) allows us to assess it as average.

To comprehensively opportunities assessment to increase the enterprise innovation activity, an integrated model (Figure 2) was developed, which is formed on the basis of a combination of assessments: Favourable Investment Business Climate of Ukraine $\left(S_{B C}\right)$, Innovation Potential of Ukraine $\left(E_{I A C}\right)$ and Innovation Activity of the enterprise $\left(V^{I A}\right)$.

The calculation of the integrated indicator of opportunities assessing for increasing the enterprise innovation activity $\left(V_{F O I A}\right) \mathrm{s}$ based on determining the total volume of the pyramid, which is carried out according to the following formulas:

$$
V_{F O_{I A}}=\int_{0}^{H} \frac{S_{B C}}{H^{2}} x^{2} d x=\left.\frac{S_{B C} x^{3}}{3 H^{2}}\right|_{0} ^{H}=\frac{1}{3} S_{B C} H,
$$

$V_{\text {FOIA }}$ - integrated indicator of opportunities assessment to increase the enterprise innovation activity, coefficient; $S_{B C^{-}}$area of the platform of innovation activity of the enterprise (complex indicator of assessment of investment business climate in Ukraine), coefficient; $H$ - the total height of innovation, the coefficient.

$$
H=H_{1} \times H_{2},
$$

$H_{1}$ - assessment of Innovation Potential of Ukraine $\left(E_{I A C}\right)$, coefficient; $\mathrm{H}_{2}$ - assessment of the level of Innovation Activity of the enterprise $\left(V^{I A}\right)$, coefficient.

Accordingly, the value of the integrated indicator of opportunities assessment to increase the enterprise innovation activity $\left(\mathrm{V}_{\text {FOIA }}\right)$ is as follows:

$$
V_{F O_{I A}}=\frac{1}{3} \times 2.252 \times(0.544 \times 1.419)=0.580 a \text {. }
$$

Opportunities assessment to increase the enterprise innovation activity is carried out on the following scale (Table 9):

According to the developed scale (Table 8), opportunities to increase the innovation activity of Ferrotrading LLC are assessed as promising $\left(V_{\text {FOIA }}=0.580\right)$. Increasing the innovation activity of Ferrotrading LLC while maintaining favourable conditions will be a powerful factor in innovative development. It should be noted that the innovation activity of the enterprise should be supported

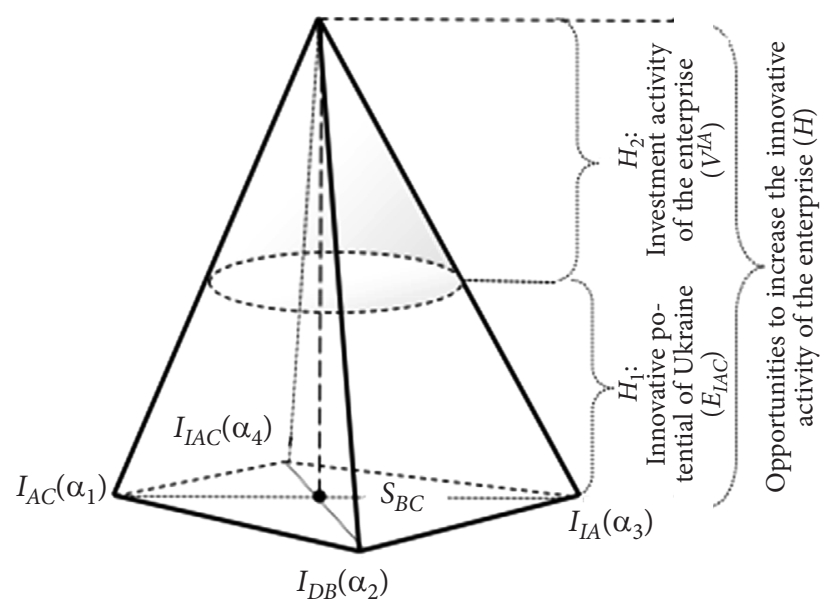

Figure. 2. The integrated model for comprehensive opportunities assessment to increase the enterprise innovation activity (developed by the authors)

Table 9. The scale of opportunities assessment favourability to increase the enterprise innovation activity (developed by the authors)

\begin{tabular}{|c|l|}
\hline $\begin{array}{c}\text { The range of values of the } \\
\text { integrated indicator } V_{F O I A}\end{array}$ & $\begin{array}{c}\text { Linguistic opportunities } \\
\text { assessment }\end{array}$ \\
\hline $0.71 \leq V_{F O I A} \leq 1.00$ & $\begin{array}{l}\text { very high opportunities to } \\
\text { increase innovation activity }\end{array}$ \\
\hline $0.51 \leq V_{F O I A} \leq 0.70$ & $\begin{array}{l}\text { promising opportunities to } \\
\text { increase innovation activity }\end{array}$ \\
\hline $0.31 \leq V_{F O I A} \leq 0.50$ & $\begin{array}{l}\text { favorable opportunities to } \\
\text { increase innovation activity }\end{array}$ \\
\hline $0.30 \leq V_{F O I A} \leq 0.16$ & $\begin{array}{l}\text { moderate opportunities to } \\
\text { increase innovation activity }\end{array}$ \\
\hline $0 \leq S V_{F O I A} \leq 0.15$ & $\begin{array}{l}\text { there are no opportunities to } \\
\text { increase innovation activity }\end{array}$ \\
\hline
\end{tabular}

by the public sector by improving the regulatory framework governing innovation activity, providing tax benefits, guarantees of intellectual property protection and protection of the interests of potential investors.

The practical value of the proposed methodological approach of opportunities assessment to increase the enterprise innovation activity lies in the possibility of reasonable determination of a set of management decisions to increase the enterprise innovation activity; defining a system of measures for the development of innovative resources, innovative competencies, innovative abilities, increasing the value of innovation, as well as the formation of appropriate strategies for the enterprise innovation development.

\section{Discussions}

The provision of progressive changes in the national economy, social and legal spheres of activity, technologies, organizational processes of companies and the implementation of innovative products depends on the direction of 
innovation in different types of entrepreneurship. Accordingly, the level of readiness of enterprises to face internal and external challenges grows, the competitiveness of products and the efficiency of enterprises increase.

Urgency of the fastest possible inculcation of innovative processes in activities of entities of Ukraine economy is demonstrated by the fact that historically Ukraine had a powerful production and resource potential, which was enough to provide the economy competitiveness and also significant increase in volume of exports therefore increasing the position of a country in the international innovation market system. However, the lack of state support for innovation policy has led to excessive saturation of the domestic market with imported products and the displacement of domestic goods.

In addition, presented results further elaboration and discussion can be conducted towards proving such hypotheses: domestic entities of a real sector of economy lack the necessary capability regarding the creation, production, market launch and selling innovative products; the economic efficiency of investment and innovation is low in the State, particularly, the volume of public and private spending on scientific, technical and research work increases due to the fact that the volume of volumes of innovative products sold rapidly decline.

The main task in the direction of increasing innovation activity is the search for and efficient use of financial resources. The investments are a means of stimulating and direct financing of innovation activities. The survival of enterprises in the conditions of instability of the external environment and their functioning depends on the introduction of innovations in the process of activity, as the results of innovation activity determine the economic stability of economic entities. The innovation activity of enterprises depends on a favourable investment environment, which is also considered legitimate, but only partially. The source of investment resources for the implementation of innovative projects can be the own funds of business entities or corporate funds.

In addition, the opportunities of innovative development and increase of the level of innovation activity of individual enterprises depends on the state of innovation potential of the country as a whole, which is confirmed by the relevant economic and mathematical calculations. It is also important to form the equation of the integrated coefficient of investment and innovation security at different hierarchical levels of management. On the basis of models of structural, econometric and comparative analysis of investment and innovation functional components it is necessary to identify the presence of such quantitative (small volumes of investments in innovative projects, small shares of investments in the value of fixed assets, volumes of economic activity, attracted capital) and qualitative (priorities of directing investments to production goals, low inventive activity of the population and limitation of practices of cooperation within the framework of innovation environment) disadvantages.
And the use of models of systemic and strategic analysis of the main macroeconomic indicators would confirm the hypothesis of a low level of efficiency of state regulation.

\section{Conclusions}

The ambiguity of the concept of "investment activity" was determined by the choice of methods for investment activity evaluation of the enterprise, which are based on an integrated indicator of the relationship between investment opportunities and investment risks. Therefore, the proposed model of opportunities assessment to increase the enterprise innovation activity is based on the growth rate of capital investment of industrial enterprises, the growth rate of foreign direct investment in industry and the share of industry in total foreign direct investment. The proposed systematic and comprehensive approach to opportunities assessment to increase the enterprise innovation activity is a necessary tool for making quality management decisions to develop the enterprise innovation potential.

Due to a comprehensive system of opportunities assessment to increase innovation activity of the enterprise, three areas of research are identified: investment business climate of the country (Competitive Attractiveness of the Country; Favourable Conditions for Doing Business in the Country; Innovation Activity), innovation potential of the country (indicators of Global Innovation Index) and, in fact, innovation enterprise activity (innovative resources and innovative competencies).

Based on the calculations and the developed rating scale the investment business climate in Ukraine is moderately favourable. The dynamic growth of investment will have a positive impact on the development of innovation in all types of economic activity. The 85th place of Ukraine in 2019 in the ranking of global competitiveness is due to such positive factors as: exchange rate stability, social cohesion, reduction of bureaucracy, growth of real GDP per capita and others. The key factors of investment attractiveness are: skilled workforce, economic dynamism, competitiveness of expenditure, high level of education. The negative dynamics of the investment attractiveness index is caused by the high levels of corruption, lack of land reform, the shadow economy, the war in the East of the country and so on. The results of the study also convincingly demonstrated the effectiveness of the country's innovation potential, despite the decrease in Ukraine's position on the value of the Global Innovation Index to 0.544 .

A generalizing indicator was the estimation of innovation activity of the enterprise in accordance with the concept of value formation of innovations. Based on the authors' proposed model for calculating the weights of each group of indicators (using the method of randomization) was developed the integrated indicator of innovation activity selected for the research of Ferrotrading LLC, which in 2019 amounted to 1.419, and according to the identification scale became average.

Previous conclusions and research served to develop an integrated model of comprehensive assessment of 
opportunities to increase innovation activity of the enterprise, combining: Indicator of assessment of the Investment Business Climate of Ukraine $\left(S_{B C}\right)$, Indicator of Innovation Potential of Ukraine $\left(\mathrm{E}_{\mathrm{IAC}}\right)$ and indicator of Innovation Activity $\left(V^{\mathrm{IA}}\right)$.

This paper is unique as we consider the proposed model is practically valuable for a set of management decisions to increase the innovation activity of the enterprise.

\section{References}

A Strategy for American innovation. (2015). National Economic Council and Office of Science and Technology Policy, October. https://obamawhitehouse.archives.gov/sites/default/files/ strategy_for_american_innovation_october_2015.pdf

Bochkovskii, A., \& Gogunskii, V. (2018). Development of the method for the optimal management of occupational risks. Eastern-European Journal of Enterprise Technologies, 3(3(93)), 6-13. https://doi.org/10.15587/1729-4061.2018.132596

Borsch, L., Vorobiev, Y., \& Bondar, A. (2016). Priorities for the formation of investment activity in the economy. Humanities, Socio-Economic and Social Sciences, (12), 225-228.

Byrka, M. I. (2017). The main trends in investment activity in Ukraine. Investments: Practice and Experience, No. 7/2017. http://www.investplan.com.ua/pdf/7_2017/7.pdf

Dokmanic, I., Parhizkar, R., Ranieri, J., \& Vetterli, M. (2015). Euclidean distance matrices: essential theory, algorithms, and applications. IEEE Signal Processing Magazine, 32(6), 12-30. https://doi.org/10.1109/MSP.2015.2398954

Drugov, O. (2010). Investment support of intellectualization of the economy of Ukraine (monograph) (284 p.). UBS NBU.

Fedulova, I. (2010). Synergetic evolutionary model of innovative development of the enterprise. Scientific Works of NUHT, 36, 114-118.

Fedulova, I. (2008). Innovative adaptive potential of the enterprise. Formation of Market Relations in Ukraine, 10, 59-64.

Frolova, L., \& Kravchenko, O. (2014). Management of enterprise business model transformation based on value spread modelling. Actual Problems of Economics, 158(8), 506-515.

Frolova, L., Ivanchuk, K., Nosova, T., Horodetska, T., \& Zaychenko, K. (2019). Evaluation of informational provision quality of food industry enterprises flexibility management. Journal of Hygienic Engineering and Design, 28, 66-72.

Grechanik, B. (2007). Innovation-oriented development of enterprises: organizational and economic aspects (187 p.). Institute for Regional Studies of the National Academy of Sciences of Ukraine, Lviv.

Ilyash, O., et al. (2020). Evaluation of enterprise investment attractiveness under circumstances of economic development. Bulletin of Geography. Socio-economic Series, 47(47), 95-113. https://doi.org/10.2478/bog-2020-0006

Ilyash, O., Dzhadan, I., \& Ostasz, G. (2018). The influence of the industry's innovation activities indices on the industrial products' revenue of Ukraine. Economics and Sociology, 11(4), 317-331. https://doi.org/10.14254/2071-789X.2018/11-4/21

Karpenko, L. M., \& Filyppova, S. (2016). Strategic competitive analysis of innovative enterprise development: Predictive validity. Actual Problems of Economics, 6(180), 392-404.

Korytko, T. (2016). Estimation of investment activity of industrial enterprises of Ukraine. Economic Bulletin of Donbass, 3(45), 141-145.

Kovtunenko, K., Kovtunenko, Y., Shatskova, L., \& Yatsenko, M., (2019). Management mechanism as an independent element of the food industry enterprise innovative activity expenditures management system. Journal of Hygienic Engineering and Design, 28, 73-80.

Kramskoy, D., \& Kolotyuk, O. (2013). Analysis of the tools of research of innovative development of the enterprise. Business Inform, 5, 253-258. https://www.business-inform.net/export_ pdf/business-inform-2013-5_0-pages-253_258.pdf

Levkivsky, O. (2017). International indicators for assessing the innovation potential of Ukraine and its implementation. Intelligence XXI, 4, 78-82.

Lupak, R. (2015). Identification of system characteristics of innovative strategy to increase the competitiveness of the enterprise. A Young Scientist, 2(2), 161-165. http://nbuv.gov.ua/UJRN/molv_2015_2(2)_40.

Lawson, B. (2001). Developing innovation capability in organizations: a dynamic capabilities approach. International Journal of Innovation Management, 5(3), 377-400. https://doi.org/10.1142/S1363919601000427

Mamatova, L. (2018). Development of innovative activity of Ukraine in the international context. Reporter of the Priazovskyi state technical university. Section: Economic sciences, 36, 279291. https://doi.org/10.31498/2225-6725.36.2018.169658

Maslak, O., \& Talover, V. (2016). Complex assessment of investment affiliation of the state. Economic Forum, 3, 51-59.

Mishra, S., Sarkar, U., Taraphder, S., Datta, S., Swain, D., Saikhom, R., et al. (2017). Multivariate statistical data analysis Principal Component Analysis (PCA). International Journal of Livestock Research, 7(5), 60-78. https://www.researchgate.net/publication/316652806_

Natorina, A. (2017). Congruent marketing product strategies of the enterprises. Economic Annals-XXI, 163(1-2(1)), 75-78. https://doi.org/10.21003/ea.V163-16

Savluk, O. (2011). Conceptual approaches to determining the investment attractiveness of the region. Bulletin of Khmelnytsky National University, 5(2), 241-245.

Shcherba, A. (2015). Investment activity of industrial enterprises of Ukraine. Strategy and mechanisms for regulating industrial development (pp. 233-243).

http://nbuv.gov.ua/UJRN/sim_2015_2015_20

The Global Innovation Index. (2019).

https://www.globalinnovationindex.org/gii-2019-report\#

Vasyltsiv, T., Lupak, R., \& Osadchuk, Yu. (2017). Assessment of the level of penetration of import dependence in the context of the import substitution policy in Ukraine. Economic Annals-XXI, 167(9-10), 13-17. https://doi.org/10.21003/ea.V167-03

Vyborova, E., \& Salyakhova, E. (2013). Methodological aspects of analysis and management of investment activity of the organization. Economic analysis: Theory and Practice, 12(315), 23-26.

World Bank. (2020). Doing Business 2020. World Bank. https://doi.org/10.1596/978-1-4648-1440-2

Wang, Y., Rosenberger, W., \& Uschner, D. (2019). Randomization-based inference and the choice of randomization procedures. Statistical Papers. https://doi.org/10.1007/s00362-018-01070-y

Yermak, S., \& Bugaenko, O. (2016). Implementation of innovative development strategy of a dairy enterprise based on a smart farm concept. Actual Problems of Economics, 12(186), $138-146$.

Yermak, S. (2017). Problems of innovative activity development at food industry enterprises of Ukraine. Journal of Hygienic Engineering and Design, 21, 96-102. 